\title{
PENGARUH MODEL PEMBELAJARAN KOOPERATIF TIPE TWO STAY TWO STRAY TERHADAP HASIL BELAJAR FISIKA SISWA KELAS VIII SMP NEGERI 3 LUBUKLINGGAU
}

\author{
Ovilia Putri Utami Gumay \\ Program Studi Pendidikan Fisika STKIP-PGRI Lubuklinggau \\ Email: zhoulia127@gmail.com
}

Submit, 22-12-2017 Accepted, 29-12-2017 Publish, 29-12-2017

\begin{abstract}
This study aims to determine whether there is an influence of Two Stay Two Stray learning model on physics learning outcomes of students of class VIII SMP Negeri 3 Lubuklinggau Lesson Year 2015/2016. This research type is experiment with design that used is pretest-posttest control group design. The population in this study is the entire class VIII SMP Negeri 3 Lubuklinggau. The sample in this research is two classes taken at random, where class VIII.2 as experiment class and class VIII.1 as class. Technique of collecting data used is test. Collected data were analyzed using $t$ test. Based on the results of analysis of pre-test data with $95 \%$ confidence level obtained tcount $=$ 0.477 and ttable $=2,000$ because tcount <ttable, then obtained the conclusion that the experimental class and ontrol class is homogeneous. While the results of post-test data analysis with $95 \%$ confidence level obtained tcount $=11.2244$ and ttable $=2,000$ because $t$ count $<$ ttable, then obtained the conclusion that there are differences in the results of physics learning between classes taught by Two Stay Two Stray learning model and class taught with lecture and question and answer method in class VIII SMP Negeri 3 Lubuklinggau Lesson Year 2015/2016.
\end{abstract}

Keywords: Two Stay Two Stay (Ts-Ts), Learning Outcome Students

Abstrak: Penelitian ini bertujuan untuk mengetahui apakah ada pengaruh model pembelajaran Two Stay Two Stray terhadap hasil belajar fisika siswa kelas VIII SMP Negeri 3 Lubuklinggau Tahun Pelajaran 2015/2016. Jenis penelitian ini adalah eksperimen dengan desain yang digunakan adalah pretest-posttest control group design. Populasi dalam penelitian ini adalah seluruh kelas VIII SMP Negeri 3 Lubuklinggau. Sampel dalam penelitian ini adalah dua kelas diambil secara acak, dimana kelas VIII.2 sebagai kelas eksperimen dan kelas VIII.1 sebagai kelas.Teknik pengumpulan data yang digunakan adalah tes. Data terkumpul dianalisis dengan menggunakan uji t. Berdasarkan hasil analisis data pre-test dengan taraf kepercayaan $95 \%$ didapat $t_{\text {hitung }}=0,477$ dan $t_{\text {tabel }}=$ 2,000karena $t_{\text {hitung }}<t_{\text {tabel, }}$ maka diperoleh simpulan bahwa kelas eksperimen dan kelas ontrol adalah homogen. Sedangkan hasilanalisis data post-test dengan taraf kepercayaan $95 \%$ didapat $t_{\text {hitung }}=$ 11,244 dan $t_{\text {tabel }}=2,000$ karena $t_{\text {hitung }}<t_{\text {tabel, }}$ maka diperoleh simpulan bahwa terdapat perbedaan hasil belajar fisika antara kelas yang diajarkan dengan model pembelajaran Two Stay Two Stray dan kelas yang diajar kan dengan metode ceramah dan tanya jawab dikelas VIII SMP Negeri 3 Lubuklinggau Tahun Pelajaran 2015/2016.

Kata kunci:Two Stay Two Stray (Ts-Ts ), Hasil Belajar Fisika.

\section{PENDAHULUAN}

Pendidikan merupakan salah satu faktor utama untuk mewujudkan masyarakat yang berkualitas. Berbagai upaya untuk meningkatkan harapan, salah satu cerminan kualitas pendidikan di sekolah adalah hasil belajar yang dicapai siswa. Dengan demikian belajar siswa pada mata pelajaran tertentu merupakan salah satu indikatorkualitas pendidikan di sekolah yang bersangkutan.

Pembelajaran fisika merupakan salah satu cabang ilmu pengetahuan alam yang mengamati tentang gejalagejala atau fenomena yang berhubungan dengan benda-benda di sekitar. Mempelajari fisika diharapkan dapat membantu manusia dalam mengatasi 
berbagai permasalahan yang dihadapinya dalam kehidupan sehari-hari. Sebagai contoh, seseorang dapat menaikkan balok yang besar ke atas mobil atau truk dengan mudah jika orang tersebut menggunakan prinsip bidang miring. Selain contoh tersebut, masih banyak contoh permasalahan kehidupan seharihari yang dapat diselesaikan dengan konsep fisika.

Fisika juga pelajaran yang memiliki peran penting dalam membentuk pola pikir siswa menjadi siswa yang berkualitas karena langsung mapun tidak langsung dalam kehidupan sehari-hari kita dapat menjumpai fenomena-fenomena yang berhubungan dengan ilmu fisika. Oleh sebab itu dalam proses pembelajaran fisika berlangsung guru mampu memiliki cara pembelajaran yang tepat agar tercapai tujuan pembelajaran yang di inginkan misalnya guru mengembangkan suatu aplikasi pembelajaran agar siswa lebih efektif dalam belajar sains dalam kelas.

Sanjaya (2009) "Model Pengajaran Kelompok adalah rangkaian kegiatan yang dilakukan oleh siswa dalam kelompok-kelompok tertentu untuk mencapai tujuan yang dirumuskan". Lie (2008) menyatakan salah satu model pembelajaran yang ada dalam model pembelajaran terpadu adalah model pembelajaran Two Stay Two Stray. Model ini memberi kesempatan kepada kelompok untuk membagikan hasil dan informasi dengan kelompok lain.

Purmiati (2012) menyatakan model pembelajaran kooperatif tipe Two Stay Two Stray akan mengarahkan siswa untuk aktif, baik dalam berdiskusi, tanya jawab, mencari jawaban, menjelaskan dan juga menyimak materi yang dijelaskan oleh teman.

Model kooperatif TwoStay Two Stray sebagai alternatif pengajaran bagi guru dalam meningkatkan hasil belajar siswa dan guru diharapkan mampu memotivasi siswa lebih aktif serta mampu menciptakan suasana kelas yang menyenangkan sehingga siswa merasa nyaman dan menjadi termotivasi untuk belajar.

Dalam kegiatan belajar dengan menggunakan model pembelajaran Two Stay Two Stray ini, model pembelajaran yang digunakan dalam mengajar fisika dengan tujuan membantu siswa mengatasi masalah dalam belajar, sehingga hasil belajar yang diperoleh bisa lebih baik dan siswa terlibat langsung dalam proses belajar mengajar. Sehingga siswa merasa dapat memecahkan suatu masalah yang dihadapi dan juga dapat meningkatkan keterampilan berkomunikasi dan bersosialisasi serta melatih keberanian dan tanggung jawab dalam menghadapi suatu permasalahan.

Berdasarkan hasil wawancara yang dilaksanakan pada tanggal 01 September 2015, kepada salah satu guru mata pelajaran IPA Terpadu di SMP Negeri 3 Lubuklinggau Tahun Pelajaran 2015/2016, diperoleh pada hasil ulangan harian fisika semester ganjil masih banyak siswa yang belum mencapai KKM (Kriteria Ketuntasan Minimal).Dari keseluruhan siswa kelas VIII sebanyak 304 orang, terdapat 123 siswa $(40,43 \%)$ yang mencapai KKM dan sebanyak 181 siswa $(59,57 \%)$ yang belum mencapai KKM, sedangkan KKM yang telah ditetapkan di sekolah tersebut sebesar 75. Hal ini menunjukkan bahwa kemampuan berpikir siswa dalam pembelajaran fisika masih lemah, sehingga mereka yang 
belum mencapai KKM harus mengikuti ujian remedial.

Salah satu penyebab rendahnya hasil belajar fisika adalah terletak antara guru, siswa, materi pelajaran serta metode belajar mengajar. Guru mempunyai peranan yang sangat penting dalam kegiatan pembelajaran karena guru merupakan salah satu kunci keberhasilan dari proses pembelajaran.Keberhasilan dalam pembelajaran merupakan suatu harapan yang besar dari seorang manusia, baik ia sebagai siswa maupun sebagai guru. Untuk memberikan keberhasilan dalam pembelajaran fisika di kelas VIII SMP Negeri 3 Lubuklinggau, perlu adanya alternatif model pembelajaran yang digunakan dalam pembelajaran fisika agar adanya pembaharuan sehingga siswa tidak lagi beranggapan bahwa pelajaran fisika itu susah dan tidak menyenangkan. Salah satu upaya yang dapat dilakukan untuk meningkatkan hasil belajar siswa pada pembelajaran fisika, yaitu guru harus berusaha mencari strategi dalam menggunakan model pembelajaran inovatif yang sesuai dengan materi yang sedang dipelajari agar siswa mampu menangkap pelajaran dengan mudah, menguasai konsep dan memicu siswa untuk berperan lebih aktif lagi dalam kegiatan belajar mengajar di kelas.

Untuk mencapai kondisi di atas, diperlukan model pembelajaran yang membuat siswa dapat aktif mengeluarkan pendapat dan menemukan konsepnya sendiri yaitu dengan menggunakan model Two Stay Two Stray. Model pembelajaran Two Stay Two Stray adalah salah satu tipe pembelajaran yang memberikan kesempatan kepada kelompok untuk membagikan hasil dan informasi dengan kelompok lain. Banyak kegiatan belajar mengajar yang diwarnai dengan kegiatankegiatan individu. Siswa berkerja sendiri dan tidak diperbolehkan melihat pekerjaan siswa lain. Padahal dalam kenyataan hidup diluar sekolah, kehidupan dan kerja manusia saling bergantungan satu sama lainnya (Lie, 2008).

Huda (2014) model kooperatif Two Stay Two Stray memberi kesempatan kepada kelompok lain untuk membagi hasil dari informasi dengan kelompok lain. Suyatno (2009) mengatakan bahwa pembelajaran model kooperatif tipe Two Stay Two Stray adalah dengan cara siswa berbagi pengetahuan dan pengelaman dengan kelompok lain. Dalam hal ini guru harus memberikan perhatian yang lebih kepada siswa dan melakukan perbaikan dan pembaharuan dalam proses pembelajaran fisika disekolah sehingga dapat meningkatkan peran aktif siswa dalam belajar.

Berdasarkan uraian tersebut, peneliti tertarik untuk mengadakan penelitian yang berjudul "Pengaruh Model Pembelajaran Kooperatif Tipe Two Stay Two Stray Terhadap Hasil Belajar Fisika Siswa Kelas VIII SMP Negeri 3 Lubuklinggau Tahun Pelajaran 2015/2016.

\section{METODE PENELITIAN}

Desain penelitian adalah semua proses yang diperlukan dalam perencanaan dan pelaksanaan penelitian. Desain eksperimen yang digunakan dalam penelitian ini adalah berbentuk PretestPosttest control Group Design atau desain kelompok kontrol eksperimen. Adapun desainnya menurut Arikunto (2010) dapat digambarkan pada tabel 1

\begin{tabular}{cccc}
\hline Group & Pre- test & Treatment & $\begin{array}{c}\text { Post- } \\
\text { test }\end{array}$ \\
\hline $\mathbf{E}$ & $\mathrm{Y}_{1}$ & $\mathrm{X}$ & $\mathrm{Y}_{2}$ \\
$\mathbf{K}$ & $\mathrm{Y}_{1}$ & - & $\mathrm{Y}_{2}$ \\
\hline
\end{tabular}

Dengan $Y_{1}$ adalah Tes pendahuluan kelas eksperimen, $\mathrm{Y}_{2}$ adalah Tes akhir kelas eksperimen, $\mathrm{Y}_{1}$ adalahTes pendahuluan kelas kontrol, $\mathrm{Y}_{2}$ adalah Tes akhir kelas kontrol dan $\mathrm{X}$ adalah Pengajaran dengan menggunakan model Two Stay Two Stray. Dalam penelitian ini, terdiri dari dua variabel yang terdiri atas 
variabel bebas dan variabel terikat. Adapun yang menjadi variabel bebas adalah model Two Stay Two Stray, sedangkan variabel terikat adalah hasil belajar fisika.

Populasi dalam penelitian ini adalah seluruh siswa kelas VIII SMP Negeri 3 Lubuklinggau Tahun Pelajaran 2015/2016 dapat dilihat pada tabel 2.

\begin{tabular}{|c|c|c|c|c|}
\hline \multirow[t]{2}{*}{ No } & \multirow[t]{2}{*}{ Kelas } & \multicolumn{2}{|c|}{ Jenis Kelamin } & \multirow[t]{2}{*}{ Jumlah } \\
\hline & & $\begin{array}{c}\text { Laki- } \\
\text { laki }\end{array}$ & $\begin{array}{c}\text { Peremp } \\
\text { uan }\end{array}$ & \\
\hline 1 & VIII.1 & 20 & 12 & 32 \\
\hline 2 & VIII.2 & 16 & 16 & 32 \\
\hline 3 & VIII.3 & 21 & 14 & 35 \\
\hline 4 & VIII.4 & 19 & 14 & 33 \\
\hline 5 & VIII.5 & 21 & 13 & 34 \\
\hline 6 & VIII.6 & 20 & 15 & 35 \\
\hline 7 & VIII.7 & 18 & 16 & 34 \\
\hline 8 & VIII.8 & 20 & 14 & 34 \\
\hline 9 & VIII.9 & 19 & 14 & 33 \\
\hline \multicolumn{2}{|c|}{ Jumlah } & 176 & 128 & 302 \\
\hline
\end{tabular}

Sampel dalam penelitian ini adalah dua kelas yang diambil secara acak dengan teknikSimpleRandom Sampling. SimpleRandom Samplingadalah pengambilan anggota sampel dari populasi dilakukan secara acak tanpa memperhatikan strata yang ada dalam populasi itu."Sampel adalah sebagian atau wakil populasi yang diteliti" (Arikunto,2010).

Dari seluruh kelas VIII diambil dua kelas secara acak untuk dijadikan sebagai sampel penelitian. Dua kelas tersebut dilakukan pengundian untuk menentukan kelas eksperimen dan kelas kontrol.Berdasarkan hasil pengundian kelas VIII.1 sebagai kelas kontrol dengan jumlah siswa sebanyak 32, sedangkan kelas VIII.2 Sebagai kelas eksperimen dengan jumlah siswa sebanyak 32 orang.

Sampel dalam penelitian ini adalah dua kelas yang diambil secara acak dengan teknikSimpleRandom Sampling. SimpleRandom Samplingadalah pengambilan anggota sampel dari populasi dilakukan secara acak tanpa memperhatikan strata yang ada dalam populasi itu."Sampel adalah sebagian atau wakil populasi yang diteliti" (Arikunto,2010).

Dari seluruh kelas VIII diambil dua kelas secara acak untuk dijadikan sebagai sampel penelitian. Dua kelas tersebut dilakukan pengundian untuk menentukan kelas eksperimen dan kelas kontrol.Berdasarkan hasil pengundian kelas VIII.1 sebagai kelas kontrol dengan jumlah siswa sebanyak 32, sedangkan kelas VIII.2 Sebagai kelas eksperimen dengan jumlah siswa sebanyak 32 orang.

Teknik pengumpulan data yang digunakan dalam penelitian ini adalah tes. Menurut Arikunto (2010) tes adalah serentetan pertanyaan atau latihan, serta alat lain yang digunakan untuk mengukur keterampilan, pengetahuan intelegensi, kemampuan atau bakat yang dimiliki oleh individu atau kelompok.Tes tersebut dilakukan sebanyak dua kali yaitu sebelum (pre-test) dan sesudah (post-test) materi yang diajarkan.

Tes hasil belajar yang digunakan dalam penelitian ini berbentuk essay sebanyak 7 soal.

Teknik analisis data dalam penelitian ini adalah dengan menggunakan

1. Menentukan Nilai Rata-Rata dan Simpangan Baku

$$
\bar{x}=\frac{\sum x_{i}}{n} \text { dan } S=\sqrt{\frac{\sum f i\left(x_{i}-\bar{x}\right)^{2}}{n-1}}
$$

Keterangan :

$\bar{x}=$ Nilai rata-rata hasil belajar siswa

$x_{i}=$ Nilai siswa secara keseluruhan

$n=$ Banyak data/sampel

$s=$ Simpangan baku

\section{Uji Normalitas Data}

$x^{2}=\sum_{i=1}^{k} \frac{\left(f_{o}-f_{h}\right)^{2}}{f_{h}}$ 
Keterangan:

$\chi^{2}=$ Harga Chi Kuadratyang dicari

$f_{0}=$ Frekuensi yang diobservasi

$f_{h}=$ Frekuensi yang diharapkan

\section{Uji Homogenitas}

$\mathrm{F}=\frac{S_{1}^{2}}{S_{2}^{2}} \quad$ atau $\quad \mathrm{F}=\frac{V_{\text {terbesar }}}{V_{\text {terkecil }}}$

Keterangan:

$S_{1}^{2:}=$ Varians terbesar

$S_{2}^{2}=$ Variasi terkecil

\section{Uji Hipotesis}

$$
t=\frac{\overline{x_{1}}-\overline{x_{2}}}{\sqrt{\frac{\left(n_{1}-1\right) s_{1}^{2}+\left(n_{2}-1\right) s_{2}^{2}}{n_{1}+n_{2}-2}\left(\frac{1}{n_{1}}+\frac{1}{n_{2}}\right)}}
$$

Keterangan :

$$
t=\text { nilai } \mathrm{t} \text { yang dihitung }
$$

$\overline{x_{1}}=$ nilai rata-rata dari kelompok

eksperimen

$\overline{x_{2}}=$ nilai rata-rata dari kelompok kontrol

$s_{1}^{2}=$ varians kelompok eksperimen

$s_{2}^{2}=$ varians kelompok kontrol

$n_{1}=$ Banyak subjek kelompok

eksperimen

$n_{2} \quad=$ Banyak subjek kelompok kontrol

$\mathrm{S} \quad=$ Simpangan baku sampel

\section{HASIL PENELITIAN DAN PEMBAHASAN}

Penelitian model pembelajaran kooperatif tipe Two Stay Two Stray (TSTS) dilaksanakan di kelas VIII SMP Negeri 3 lubuklinggau Tahun Pelajaran 2015/2016 dilakukan pada tanggal 01 Februari sampai $27 \quad$ Februari 2016.Populasi dalam penelitian ini adalah seluruh siswa kelas VIII yang terdiri dari sembilan kelas, dari sembilan kelas diambil dua kelas untuk dijadikan sebagai sampel penelitian yaitu kelas VIII.1 dan VIII.2 untuk melaksanakan tes awal dan tesakhir. Instrumen dalam penelitian ini berbentuk essay yang berjumlah tujuh butir soal.Setelah dilakukan wawancara secara langsung dengan guru mata pelajaran Fisika kelas VIII.1 dan VIII.2 memiliki kemampuan yang relatif sama (homogen) maka dilakukan pengundian Simple Random Sampling, setelah dilakukan pengundian maka terpilih kelas VIII.1 berjumlah 32 siswa sebagai kelas eksperimen diberikan perlakuan dengan menggunakan model pembelajaran tipe Two Stay Two Stray dan kelas VIII.2 berjumlah 32 siswa sebagai kelas kontrol diberikan perlakuan dengan metode ceramah dan tanya jawab.

Jumlah pertemuan tatap muka yang dilakukan adalah empat kali pertemuan dengan rincian satu kali pemberian pretest (kemampuan awal siswa sebelum mendapatkan perlakuan), dua kali proses pembelajaran dengan model Two Stay Two Stray (TS-TS) dan satu kali post-test (kemampuan siswa setelah mendapatkan perlakuan) dilakukan pada kegiatan pembelajaran di pertemuan terakhir. Pemberian tes awal bertujuan untuk mengetahui kemampuan awal siswa pada materi Energi sebelum diberikan perlakuan yang berbeda, sedangkan tes akhir diberikan untuk mengetahui apakah ada penggaruh hasil belajar siswasetelah diterapkan model pembelajaran tipe Two Stay Two Stray.

\section{Kemampuan Awal Siswa}

Pelaksanaan pre-test dilaksanakan pada pertemuan pertama yaitu pada tanggal 3 Februari 2016 dan diikuti oleh 32 siswa pada kelas eksperimen dan tanggal 3 Februari hari yang sama diikuti 32 siswa pada kelas kontrol. Soal pre-test dengan materi energi terdiri 7 butir soal yang berbentuk essay yang telah diketahui validitas, reliabilitas, daya pembeda dan tingkat kesukaran soal.Pelaksanaan pretest bertujuan untuk mengetahui kemampuan awal siswa pada materi energi. Hasil pre-test tersebut mengambarkan kesiapan siswa dalam 
menerima pembelajaran yang akan disampaikan oleh guru.

Adapun data hasil perhitungan pre-test siswa mengenai materi energi secara rinci dapat dilihat sebagai berikut:

a. Rata-rata $(\bar{x})$ dan Simpangan Baku (S) Pre-Test

Hasil rekapitulasi rata-rata $(\bar{x})$ dan simpangan baku(s) pre-test di kelas eksperimen dan kelas kontroldapat dilihat pada tabel 3

\begin{tabular}{ccc}
\hline Kelas & $\begin{array}{c}\text { Rata- } \\
\text { rata }(\overline{\boldsymbol{x}})\end{array}$ & $\begin{array}{c}\text { Simpang } \\
\text { an baku } \\
\text { (s) }\end{array}$ \\
\hline $\begin{array}{c}\text { Eksperim } \\
\text { en }\end{array}$ & 30,06 & 9,26 \\
Kontrol & 26,41 & 10,46 \\
\hline
\end{tabular}

Berdasarkan tabel 4.1 di atas, dapat dilihat bahwa nilai rata-rata hasil belajar pre-test yang diperoleh pada kelas eksperimen (VIII.1) 30,06 dan pada kelas kontrol (VIII.2) 26,41, sedangkan simpangan baku pada kelas eksperimen (VIII.1) 9,26 dan pada kelas kontrol (VIII.2) 10,46 untuk mengetahui bahwa hasil pre-test pada kelas eksperimen (VIII.2) dan pada kelas kontrol (VIII.2).

b. Uji normalitas

Untuk mengetahui kenormalan data pre-test maka digunakan uji normalitas dengan uji kecocokan (Chi kuadrat). Berdasarkan ketentuan perhitungan statistik mengenai uji normalitas data dengan taraf kepercayaan $=0,05$ maka dinyatakan bahwa data berdistribusi normal dalam hal lainnya tidak berdistribusi normal. Hasil uji normalitas dapat dilihat pada tabel 4 .

\begin{tabular}{|c|c|c|c|c|}
\hline Kelas & $\begin{array}{l}X_{\text {hit }}^{2} \\
\text { ung }\end{array}$ & $\begin{array}{l}\text { D } \\
k\end{array}$ & $\begin{array}{l}X^{2} \\
\text { tab } \\
\text { el } \\
\end{array}$ & $\begin{array}{l}\text { Kesi } \\
\text { mp } \\
\text { ulan }\end{array}$ \\
\hline $\begin{array}{l}\text { Eksp } \\
\text { erime } \\
\text { n }\end{array}$ & 1,60 & 5 & $\begin{array}{l}12 \\
, 6 \\
0\end{array}$ & $\begin{array}{l}\text { Nor } \\
\text { mal }\end{array}$ \\
\hline $\begin{array}{l}\text { Kont } \\
\text { rol }\end{array}$ & 2,49 & 7 & $\begin{array}{l}11 \\
, 0 \\
7\end{array}$ & $\begin{array}{l}\text { Nor } \\
\text { mal }\end{array}$ \\
\hline
\end{tabular}

Pada tabel 4.2 menunjukan bahwa nilai $\mathrm{X}^{2}$ hitung data tes awal untuk kelas eksperimen dan kelas kontrol kurang $\mathrm{X}_{\text {tabel. }}^{2}$. Berdasarkan ketentuan pengujian normalitas dengan menggunakan uji kecocokan $\mathrm{X}^{2}$ dapat disimpulkan bahwa tes awal kelas eksperimen dan kelas kontrol berdistribusi normal pada taraf kepercayaan $\alpha=0,05$ dan (dk) k-1 $=5$.

c. Uji homogenitas

Uji homogenitas ini bertujuan untuk melihat apakah data pada kedua kelas sampel mempunyai varian yang homogen atau tidak. Berdasarkan ketentuan perhitungan statistika, tentang uji homogenitas varians dengan taraf kepercayaan $\alpha=0,05$, jika $F_{\text {hitung }}<\mathrm{F}_{\text {tabel }}$ maka varians dua kelompok data adalah homogen. Hasil uji homogenitas varians tes awal untuk kelas eksperimen dan kelas kontrol dengan taraf kepercayaan $\alpha=0,05$ dapat dilihat pada tabel 5

\begin{tabular}{ccccc}
\hline Tes & $\mathbf{F}_{\text {hitung }}$ & Dk & $\mathbf{F}_{\text {tabel }}$ & $\begin{array}{c}\text { Kesimp } \\
\text { ulan }\end{array}$ \\
\hline $\begin{array}{c}\text { Pre- } \\
\text { test }\end{array}$ & 1,27 & $31: 3$ & 1,79 & $\begin{array}{c}\text { Homog } \\
\text { en }\end{array}$ \\
\hline
\end{tabular}

Pada tabel 4.3 menunjukan bahwa varians kedua kelompok data (kelas eksperimen dan kelas kontrol) pada pre-test adalah homogen, karena $\mathrm{F}_{\text {hitung }}<\mathrm{F}_{\text {tabel }}$ pada taraf kepercayaan $\alpha=0,05$.

d. Uji Kesamaan Dua Rata-Rata

Uji kesamaan dua rata-rata bertujuan untuk mengetahui ada atau tidaknya perbedaan pada kemampuan awal siswa yaitu pada kelompok eksperimen dan kelompok kontrol. Kriteria pengujian adalah $\mathrm{H}_{\mathrm{O}}$ diterima jika $t_{\text {hitung }} \leq t_{\text {tabel }}$ dan $\mathrm{H}_{\mathrm{O}}$ ditolak jika $t_{\text {hitung }} \geq t_{\text {tabel }}$. Berdasarkan hasil uji normalitas dan uji homogenitas, maka kedua kelompok pre-test adalah normal dan homogen. Dengan demikian uji hipotesis antara kelas eksperimen dan kelas kontrol dapat menggunakan uji-t, 
hasil untuk pre-test dapat dilihat pada tabel 6

\begin{tabular}{ccccc}
\hline Tes & $\mathbf{t}_{\text {hitung }}$ & $\mathbf{D k}$ & $\mathbf{t}_{\text {tabel }}$ & Kesimpulan \\
\hline $\begin{array}{c}\text { Pre }- \\
\text { test }\end{array}$ & 1,477 & 62 & 2,0 & $\mathrm{H}_{\mathrm{O}}$ \\
& & & 00 & diterima \\
\hline
\end{tabular}

Pada tabel 4.4 menunjukan bahwa hasil analisis uji-t data pre-test dapat disimpulkan bahwa tidak terdapat perbedaan yang signifikan kemampuan awal siswa kelas eksperimen dan kelas kontrol taraf kepercayaan $\alpha=0,05$.

\section{Kemampuan Akhir Siswa}

Pelakasanaan post-test diadakan pada pertemuan terakhir yaitu pada tanggal 10 Februari 2016 di kelas eksperimen dan di kelas kontrol. Tes akhir digunakan untuk mengetahui pengaruh penggunaan model pembelajaran Two Stay Two Stray pada kelas eksperimen dan penggunaan metode ceramah dan tanya jawab pada kelas kontrol terhadap hasil belajar siswa. Kemampuan akhir siswa dalam penguasaan materi merupakan hasil belajar siswa setelah mengikuti proses pembelajaran. Soal yang digunakan terdiri dari 7 butir soal.

a. Rata-rata $(\bar{x})$ dan Simpangan Baku (S) Post-test.

Hasil rekapitulasi perhitungan ratarata $(\bar{x})$ dan simpangan baku(s) post-test di kelas eksperimen dan kelas kontroldapat dilihat pada tabel 7

\begin{tabular}{ccc}
\hline Kelas & $\begin{array}{c}\text { Rata- } \\
\text { rata }(\overline{\boldsymbol{x}})\end{array}$ & $\begin{array}{c}\text { Simpangan } \\
\text { baku (s) }\end{array}$ \\
\hline Eksperimen & 90,81 & 7,32 \\
Kontrol & 67,31 & 9,31 \\
\hline
\end{tabular}

Berdasarkan tabel 4.5 di atas, dapat dilihat bahwa nilai rata-rata hasil belajar post -test yang diperoleh kelas eksperimen (VIII.1) 90,81 dan kelas kontrol (VIII.2) 67,31 sedangkan simpangan bakupada kelas eksperimen 7,32 dan simpangan baku pada kelas kontrol
9,31 untuk mengetahui bahwa hasil post -test kelas eksperimen dan kelas kontrol terdapat perbedaan yang cukup besar.

b. Uji normalitas

Berdasarkan ketentuan perhitungan statistik mengenai uji normalitas data dengan taraf kepercayaan $=0,05$ jika, maka dinyatakanbahwa data berdistribusi normal dalam hal lainnya tidak berdistribusinormal.Hasil uji normalitas dapat dilihat pada tabel 8

\begin{tabular}{ccccc}
\hline Kelas & $\mathbf{X}_{\text {hitung }}$ & $\begin{array}{c}\mathbf{d} \\
\mathbf{k}\end{array}$ & $\mathbf{X}_{\text {tabel }}$ & $\begin{array}{c}\text { Kesimp } \\
\text { ulan }\end{array}$ \\
\hline Eksperimen & 9,55 & 6 & 11,07 & Normal \\
Kontrol & 8,11 & 6 & 11,07 & Normal \\
\hline
\end{tabular}

Pada Tabel 4.6 menunjukan bahwa nilai $\mathrm{X}_{\text {hitung data tes awal untuk kelas }}^{2}$ eksperimen dan kelas kontrol kurang $\mathrm{X}_{\text {tabel. }}^{2}$ Berdasarkan ketentuan pengujian normalitas dengan menggunakan uji kecocokan $\mathrm{X}^{2}$ (chi-kuadrat) dapat disimpulkan bahwa tes akhirl kelas eksperimen dan kelas kontrol berdistribusi normal pada taraf kepercayaan $\alpha=0,05$ dan derajat kebebasan $(\mathrm{dk})=\mathrm{k}-1=5$.

c. Uji homogenitas

Berdasarkan ketentuan perhitungan statistika, tentang uji homogenitas varians dengan taraf kepercayaan $\alpha=0,05$, jika $\mathrm{F}_{\text {hitung }}<\mathrm{F}_{\text {tabel }}$ maka varians dua kelompok data adalah homogen. Hasil uji homogenitas varians tes akhir untuk kelas eksperimen dan kelas kontrol dengan taraf kepercayaan $\alpha=0,05$ dapat dilihat pada

\begin{tabular}{ccccc}
\hline Tes & $\mathbf{F}_{\text {hitung }}$ & Dk & $\mathbf{F}_{\text {tabel }}$ & Kesimpulan \\
\hline $\begin{array}{c}\text { Post- } \\
\text { test }\end{array}$ & 1,62 & $31: 31$ & 1,79 & Homogen \\
\hline
\end{tabular}

Pada tabel 4.7 menunjukan bahwa varians kedua kelompok data (kelas eksperimen dan kelas kontrol) pada post-test adalah homogen, karena $\mathrm{F}_{\text {hitung }}<\mathrm{F}_{\text {tabel }}$ pada taraf kepercayaan $\alpha=0,05$.

d. Uji Kesamaan Dua Rata-rata 
Hasil perhitungan menunjukan bahwa data hasil belajar siswa kelas eksperimen dan kelas kontrol berdistribusi normal dan homogen. Dengan demikian uji hipotesis antara kelas eksperimen dan kelas kontrol dapat menggunakan uji-t, hasil untuk post-test dapat dilihat pada tabel 10

\begin{tabular}{lllll}
\hline Data & $\mathbf{t}_{\text {hitung }}$ & $\mathbf{d k}$ & $\mathbf{t}_{\text {tabel }}$ & $\begin{array}{l}\text { Kesimpula } \\
\mathbf{n}\end{array}$ \\
\hline $\begin{array}{l}\text { Post- } \\
\text { test }\end{array}$ & 11,24 & 62 & 1,67 & $\mathrm{H}_{\mathrm{O}}$ ditolak \\
& 4 & & 1 & \\
\hline
\end{tabular}

Pada tabel 4.8 menunjukan bahwa hasil analisis uji-t data post-test dapat disimpulkan bahwa $t_{\text {hitung }}>t_{\text {tabel }}$ maka $\mathrm{H}_{\mathrm{O}}$ ditolak dan $\mathrm{H}_{\mathrm{a}}$ diterima, Hal ini menunjukan bahwa hipotesis yang diajukan dapat di terima kebenarannya. Setelah diberikan pembelajaran yang berbeda dimana kelas eksperimen diajarkan dengan menggunakan model pembelajaran kooperatif tipe Two Stay Two Stray dan kelas kontrol diajarkan dengan menggunakan pembelajaran metode ceramah dan tanya jawab, untuk kelas eksperimen dan kelas kontrol terjadi peningkatan nilai. Hipotesis stastistik yang diuji dalam perhitungan uji-t untuk tes akhir adalah :

$\mathrm{H}_{\mathrm{o}}: \mu_{1} \leq \mu_{2}=$ Hipotesis nol atau hipotesis pembanding, nilai rata-rata hasil belajar kelas eksperimen kurang dari atau sama dengan ratarata nilai kontrol.

$\mathrm{H}_{\mathrm{a}}: \mu_{1}>\mu_{2}=$ Hipotesis aternatif atau kerja, rata-rata nilai kelas eksperimen lebih besar dari nilai ratarata nilai kontrol.

\begin{tabular}{ccccc}
\hline Kelas & \multicolumn{2}{c}{ Pre-Test } & \multicolumn{2}{c}{ Post-Test } \\
\cline { 2 - 5 } & $\begin{array}{c}\text { Rata- } \\
\text { rata }(\bar{x})\end{array}$ & $\begin{array}{c}\text { Simpangan } \\
\text { baku (s) }\end{array}$ & $\begin{array}{c}\text { Rata- } \\
\text { rata }(\bar{x})\end{array}$ & $\begin{array}{c}\text { Simpangan } \\
\text { baku (s) }\end{array}$ \\
$\begin{array}{c}\text { Eksper } \\
\text { imen }\end{array}$ & 30,06 & 9,26 & 90,81 & 7,32 \\
$\begin{array}{c}\text { Kontr } \\
\text { ol }\end{array}$ & 26,41 & 10,46 & 67,31 & 9,31 \\
\hline
\end{tabular}

Berdasarkan uraian tersebut dapat dilihat gambaran perbandingan nilai ratarata pre-test dan post-test pada gambar 4.5.

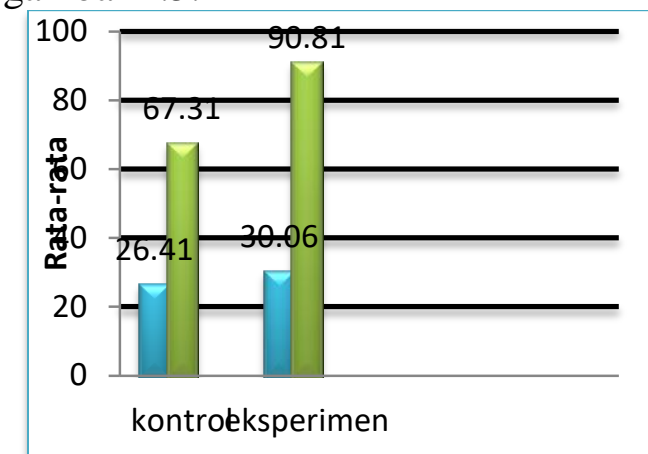

Dari data tersebut menunjukan bahwa kemampuan awal (pre-test) antara kelas eksperimen dan kelas kontrol relatif sama, karena kelas eksperimen dan kelas kontrol belum diberikan perlakuan pembelajaran. Pada pertemuan selanjutnya kelas eksperimen akan diberi perlakuan pembelajaran yang menggunakan model Two Stay Two Stray dan kelas kontrol menggunakan metode ceramah dan Tanya jawab. Sedangkan hasil tes kemampuan akhir (post -test) antara kelas eksperimen dan kelas kontrol terdapat perbedaan yang cukup besar, karena kelas eksperimen dan kelas kontrol telah diberikan perlakuan pembelajaran.

Permasalahan yang dibahas dalam penelitian ini yaitu apakah ada pengaruh yang signifikan model pembelajaran Two Stay Two Stray terhadap hasil belajar fisika siswa kelas VIII pada materi Energi. Kemudian kedua kelompok diberi perlakuan yang berbeda, yaitu kelas eksperimen diberi perlakuan dengan menggunakan model Two Stay Two Stray sedangkan kelas kontrol diberi perlakuan dengan metode ceramah dan tanya jawab.

Pada kelas eksperimen, proses belajar berlangsung menyenangkan. Dengan adanya siswa berbagi pengetahuan dan pengelaman dengan kelompok lain. Selain itu, proses belajar ini melibatkan siswa secara aktif, dalam penerapannya siswa dibentuk menjadi kelompok kecil dan kelompok itu dibagi lagi, dimana dua orang tinggal dikelompoknya sedangkan dua orang lain bertamu ke kelompok 
lainmencari informasi. Pembagian kelompok terdiri dari 4 orang siswa heterogen.

Pembelajaran diawali dengan penyampaian materi tentang energi lalu pemberian tugas kelompok. Pada saat menyelesaikan tugas kelompoknya siswa saling membantu mengerjakan dan memahaminya, setelah mereka bekerja kelompok dalam satu tim dan semua kelompok yang lain sudah mengerjakan tugasnya masing-masing lalu hasil kerja mereka disharing dari satu kelompok ke kelompok lain dan membandingkan dan membahas hasil pekerjaan mereka semua. Hal tersebut membuat siswa mulai terbiasa dengan pembelajaran menggunakan model Two Stay Two Stray serta siswa juga terlihat bersemangatpada saat diberi soal latihan.

Berbeda dengan pembelajaran yang dilaksanakan pada kelas kontrol, pembelajara yang menggunakkan metode ceramah dan tanya jawab. Pada saat guru menjelaskan materi pelajaran siswa sibuk sendiri dan berdiskusi dengan teman di sampingnya.Kegiatan ini hanya berpusat pada guru, sehingga siswa menjadi pasif.Pada saat guru bertanya siapa yang belum mengerti, siswa hanya diam sehingga membuat guru kurang mengetahui batas pemahaman siswa.

Berdasarkan analisis data post-test pada kelas eksperimen nilai rata-rata yang diperoleh siswa telah mencapai kriteria ketuntasan minimal (KKM) yang ditetapkan sebesar 75. Banyak siswa yang belum mencapai kriteria ketuntasan minimal (KKM) adalah 2 siswa dari 32 siswa. Sedangkan analisis post-test pada kelas kontrol siswa yang belum mencapai $\begin{array}{lll}\text { kriteria ketuntasan } & \text { (KKM) } 19\end{array}$ siswa.Dengan demikian nilai peningkatan hasil belajar siswa fisika yang menggunakan model pembelajaran Two Stay Two Stray lebih tinggi dari pada peningkatan hasil belajar siswa fisika yang mengggunakan metode ceramah dan Tanya jawab.

\section{SIMPULAN}

Berdasarkan hasil penelitian dan pembahasan rata-rata nilai pre-test hasil belajar kelas eksperimenyang diperoleh siswa sebesar 33,97 dan kelas kontrol sebesar 32,53 dan rata-rata nilai post-test hasil belajar kelas eksperimenyang diperoleh siswa sebesar 90,81 dan kelas kontrol sebesar 60,63. Dapat disimpulkan bahwa Ada Pengaruh Penggunaan Model Pembelajaran Kooperatif Tipe Two Stay Two Stray Terhadap Hasil Belajar Fisika Siswa Kelas VIII SMP Negeri 3 Lubuklinggau Tahun Pelajaran 2015/2016.

Berdasarkan hasil penelitian dan kesimpulan diatas, maka penulis mengemukakan saran-saran sebagai berikut :

1. Siswa diharapkan hendaknya lebih banyak lagi mengerjakan tugas yang diberikan oleh guru dan memperhatikan penjelasan dari guru.

2. Guru diharapkan dapat lebih memotivasi siswa untuk lebih aktif sehingga terjalin komunikasi yang baik antara siswa dengan siswa ataupun antara guru dengan siswa.

3. Model pembelajaran Two Stay Two Stray ini sebagai alternatif untuk diterapkan pada materi yang lain sehingga dapat meningkatkan keaktifan siswa dan dapat memaksimalkan hasil pembelajaran.

4. Peneliti lain diharapkan juga untuk menerapkan model Two Stay Two Stray ini batasan masalah yang berbeda.

5. Perlu adanya penelitian lebih lanjut sebagai pengembangan dari penelitian 


\section{DAFTAR PUSTAKA}

Arikunto, S. (2011).Prosedur Penelitian Suatu Pendekatan Praktek. Jakarta: Rineka Cipta.

Huda,Miftahul. (2013).Cooperative Learning Metode, Teknik, Struktur dan Model penerapan.Yogyakarta:Pustaka Belajar.

Lie, Anita.(2008). Mempraktikkan Cooperatif Learning di Ruangruang Kelas.Jakarta : PT. Gramedia.

Sanjaya, Wina. (2009). Strategi Pembelajaran Berorientasi Standar Proses.

Suyatno. (2009). Menjelajah Pembelajaran Inovatif. Sidoarjo: Mas Media Buana Pustaka 